\title{
Re Holy Trinity, Sittingbourne
}

Canterbury Commissary Court: Gasztowicz Dep Com Gen, 7 February 2018

[2018] ECC Can 1

Removal of pews - Victorian church - harm

The incumbent and churchwardens sought a faculty permitting the levelling of the floor and removal of all of the pews from the nave of this Grade II listed Victorian church. The pews were to be replaced with metal-framed upholstered stacking chairs. The Victorian Society raised objections, as did a local historian, although neither chose to become a party opponent. The nave pews were original to the church at the time of its construction in 1869, with much of the original Victorian numbering still evident. The court held that the removal of the pews would cause considerable harm to the significance of the building. Though simple, the pews were original Victorian pews in an original Victorian church and therefore of considerable significance to the church as a building of special historical interest. This was not a case where the removal of Victorian fittings from, for example, a medieval church was proposed. It had not been shown that the bulk of the needs identified by the petitioners could not be met by a reduced scheme which retained at least some of the pews, albeit possibly relocated. The proposed change would not be reversible and the proposed replacement chairs were not likely to be appropriate in the church. The petition was dismissed. [RA]

doi:10.1017/So956618X18000807

\section{Re Bingham Cemetery}

Southwell and Nottingham Consistory Court: Ockleton Ch, 15 February 2018

[2018] ECC S\&N 1

Exhumation

The petitioner sought a faculty for the exhumation of the remains of her husband and daughter from the cemetery at Bingham. The daughter had been buried there after dying at the age of six months in 1948 and the husband was buried in the same grave in 1989 . Bingham was the usual cemetery to bury residents of Gamston, which was seven miles away and where the family had roots. The petitioner's other daughter and son-in-law had bought plots in Wilford Hill Cemetery, a mile from Gamston, with a view to their being buried there along with the petitioner in due course. Accordingly, the petition sought exhumation of the remains of the daughter and husband to establish a 
family grave, arguing that the unexpected circumstances of the daughter's death, the distance of Bingham from Gamston and the intention now to create a family grave should constitute exceptional circumstances justifying exhumation.

The chancellor set out the principles governing the application, namely the permanence of Christian burial, as laid down in Re Christ Church, Alsager [1999] Fam 142 and Re Blagdon Cemetery [2002] Fam 299. He touched briefly on the possible conflict of authority between the two decisions and between ecclesial provinces as noted in Re St Chad, Bensham [2016] ECC Dur 2. Following Bensham, the chancellor found that Alsager is binding in the northern province, either as the appellate court of that province or as a decision of a quasibidivisional appellate court with temporal priority over Blagdon. He noted that the factual matrices for what is exceptional differ in Blagdon and Alsager but neither is an exhaustive list of exceptional circumstances. Exceptional circumstances are facts not law and therefore not bound by precedent. In this case, reviewing the various categories of circumstances the chancellor found that the proposal would not create a family grave as one already existed at Bingham, where there was space for the petitioner to be interred. There was no mistake at the time of the burials at Gamston. There were therefore no exceptional grounds justifying exhumation. The faculty was refused. [Catherine Shelley]

\section{Re Southstoneham Cemetery}

Winchester Consistory Court: Ormondroyd Ch, 19 February 2018 [2018] ECC Win 2 Exhumation - illegal use of reserved plot

In 1999 the petitioner purchased the exclusive rights of burial for grave plot 107 adjoining that of his late sister. In the intervening years two other adjoining plots were used or reserved by family members, providing a square of family graves. In February 2016 Mrs Sutton's remains were buried in plot 107. When enquiries were made it transpired that council records showed a transfer of the petitioner's reservation, apparently in 1999, from plot 107 to another plot nearby, apparently at the request of the family. It was held that the petitioner had not requested the transfer, which remained unexplained, and the council accepted that it had been at fault in its processes. After lengthy efforts and correspondence, the petitioner now sought the exhumation of Mrs Sutton's remains from plot 107 in order that it would once more be available to him.

The chancellor considered whether the petitioner in fact held exclusive rights of burial in relation to plot 107 in 2016. Although the council register benefitted 